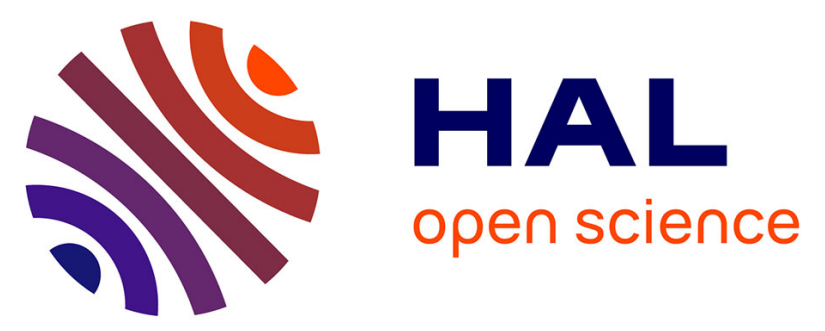

\title{
Environmental impacts of unmanaged solid waste at a former base metal mining and ore processing site (Kirki, Greece)
}

\author{
Alexandros Liakopoulos, Bruno Lemiere, Konstantinos Michael, Catherine \\ Crouzet, Valérie Laperche, Ioannis Romaidis, Iakovos Drougas, Arnault Lassin
}

\section{- To cite this version:}

Alexandros Liakopoulos, Bruno Lemiere, Konstantinos Michael, Catherine Crouzet, Valérie Laperche, et al.. Environmental impacts of unmanaged solid waste at a former base metal mining and ore processing site (Kirki, Greece). Waste Management and Research, 2010, 28 (11), pp.996-1009. 10.1177/0734242X10375746. hal-00553648

\section{HAL Id: hal-00553648 \\ https: / hal-brgm.archives-ouvertes.fr/hal-00553648}

Submitted on 30 Jan 2014

HAL is a multi-disciplinary open access archive for the deposit and dissemination of scientific research documents, whether they are published or not. The documents may come from teaching and research institutions in France or abroad, or from public or private research centers.
L'archive ouverte pluridisciplinaire HAL, est destinée au dépôt et à la diffusion de documents scientifiques de niveau recherche, publiés ou non, émanant des établissements d'enseignement et de recherche français ou étrangers, des laboratoires publics ou privés. 


\section{Environmental impacts of unmanaged solid waste at a former base metal mining and ore processing site (Kirki, Greece)}

Alexandros Liakopoulos ${ }^{1^{*}}$, Bruno Lemière ${ }^{2}$, Konstantinos Michael ${ }^{1}$, Catherine Crouzet $^{2}$, Valérie Laperche ${ }^{2}$, loannis Romaidis ${ }^{1}$, lakovos Drougas ${ }^{1,}$ Arnault Lassin ${ }^{2}$

${ }^{1}$ Institute of Geology and Mineral Exploration (IGME), Entrance C of Olympic Village, 13677 Acharnai, Greece

${ }^{2}$ Bureau de Recherches Geologiques et Minieres (BRGM), 3 Avenue Claude Guillemin, 45060, Orléans, France

*Alexandros Liakopoulos IGME Entrance C of Olympic Village, 13677 Acharnai, Greece.

E- Mail : aliakopoulos@igme.gr 


\section{ABSTRACT}

The Kirki project was aimed at identifying, among the mining waste abandoned at a mine and processing plant, the most critical potential pollution sources, the exposed milieus and the main pathways for contamination of a littoral area. This was accompanied by the definition of a monitoring network and remediation options.

In this purpose, field analytical methods were extensively used to allow a more precise identification of the source, to draw relevant conceptual models and outline a monitoring network. Data interpretation was based on temporal series and on a geographical model. A classification method for mining waste was established, based on data on pollutant contents and emissions, and their long-term pollution potential.

Mining waste present at the Kirki mine and plant sites comprises (a) extraction waste, mainly metal sulphide-rich rocks; (b) processing waste, mainly tailings, with iron and sulphides, sulphates or other species, plus residues of processing reagents; and (c) other waste, comprising leftover processing reagents and $\mathrm{Pb}-\mathrm{Zn}$ concentrates. Critical toxic species include cadmium and cyanide. Stormy rainfall regime and hilly topography favour the flush release of large amounts of pollutants. The potential impacts and remediation options vary greatly. Type $\mathrm{C}$ waste may generate immediate and severe chemical hazards, and should be remediated urgently by careful removal, as it is localised in a few spots. Type B waste has significant acid mine drainage (AMD) potential and contains significant amounts of bioavailable heavy metals and metalloids, but they may also be released in solid form towards surface water through dam failure.

The most urgent action is thus dams consolidation. Type A waste is by far the most bulky one, and it cannot be economically removed. Unfortunately, it is also the most prone to AMD (seepage $\mathrm{pH} 1$ to 2). This requires neutralization to prevent acid water to accelerate heavy metals and metalloids transfer. All waste management options require the implementation of a monitoring network for remediation plan design, efficiency control, and later, community alert in case of accidental failure of mitigation/remediation measures. A network design strategy based on field measurements, laboratory validation and conceptual models is proposed.

Keywords: Acid mining drainage; heavy metals; monitoring; bioavailability; toxicity; hazardous waste. 


\section{INTRODUCTION}

\subsection{Mining waste classification}

A mine site is usually a complex industrial system handling huge amounts of rocks in order to extract from them a lower or marginal amount of valuable metals or minerals. It comprises thus two activities: extraction and ore processing. The sheer mass of the handled material implies that the valuable commodity is extracted or concentrated near the site, and most of the waste is disposed of nearby. The specificity of mining waste required adapted regulations and standards (EU, 2006a; JRC, 2004). Applying standard industrial waste regulations to the mining sector would lead to economically unrealistic requirements, as well as inefficient solutions (Charbonnier, 2001; Symonds \& COWI, 2001).

Mining waste present at most metal mine sites comprises thus three very different types:

A -Extraction waste, constituted of rocks with variable amounts of ore and other metals. Waste heaps are potentially hazardous through acid mine drainage (AMD), requiring adequate water management (JRC, 2004);

B - Final processing waste, or tailings, constituted mainly of rock particles, with variable amounts of residual metals, and various species, plus residues of processing reagents. Tailings contain significant amounts of bioavailable heavy metals and metalloids (Concas et al., 2006), but they may also be released in solid form towards surface water through tailings dam failure (Rico et al., 2008). The most important remediation step is an adequate dam and water management (JRC, 2004);

C - Hazardous industrial waste, comprising unused leftover processing reagents, metal concentrates and other ore processing waste.

\subsection{Mining waste impacts}

The potential impacts and remediation options for these three categories varies greatly.

Former mine sites are frequently sources of pollution many years after closure, especially for heavy metals and metalloids. Specific geochemical phenomena such as acid mine drainage (AMD), acid rock drainage (ARD) contribute to increase such environmental impacts. They may be mitigated, provided that adequate remediation measures are taken at the time of mine closure. In other cases, when a site is abandoned and left to itself and exposed to the environment, impacts may be worse, and evolve unfavourably with time. Other unfavourable factors include the proximity to exposed resources, such as groundwater, cultivated areas, urban settlements or seaside.

\subsection{The case study}

Such a situation is observed at Kirki (Thrace, $22 \mathrm{~km} \mathrm{NW}$ Alexandroupolis, Figure 1), where mining and ore beneficiation for $\mathrm{Cu}, \mathrm{Zn}$ and $\mathrm{Pb}$ ceased in 1995 and where no remediation action was taken (Michael \& Dimadis, 2006a, 2006b; Liakopoulos 2009; Triantafyllidis et al., 2007). Tailings and impoundments were exposed to atmospheric conditions and were affected in their chemical, mineralogical, physical and geotechnical characteristics. Climate, which can be an important instability factor, is rough in the Kirki area, with hot and dry conditions during summer, and cold, rainy and windy days in the winter (temperate Mediterranean continental climate). The mean temperature in Alexandroupolis ranges from $8.5^{\circ} \mathrm{C}$ (January) to $30.1^{\circ} \mathrm{C}$ (August) (Romaidis, 2007). The range is even higher at Kirki due to the local foothills microclimate and the distance from the coast.

Drainage from the Kirki mine is collected by the Kirkalon brook, joining a small river, Eirini, near the plant (Figures 1, $2 \& 3$ ), itself reaching the sea near Alexandroupolis through a cultivated plain overlying aquifers used for water supply.

A monitoring program was implemented in 2005 by IGME, with the support of the European Union structural funds (3rd Community support framework, Ministry of Development, Operational Programme "Competitiveness" (O.P.C.), project 65231). During the project, two reconnaissance 
missions were led by IGME and BRGM to test the feasibility of the implementation of on-site analysis within the monitoring program. These tests provided enough data to classify waste types, identify the main pathways for emissions and to support the network design by conceptual models. The present paper is based on data and observations collected during these missions, along with regular monitoring data and observations gathered by IGME geoscientists (Michael \& Dimadis, 2006a, 2006b; Romaidis 2007; Liakopoulos 2009).

\section{MATERIALS AND METHODS}

\subsection{Scope of the work}

The study was focused on chemical impacts, and it was aimed at characterizing geochemically the sources and their emissions towards the environment. The impact itself on potential receptors was identified (presence and concentration of contaminants) in order to design a relevant monitoring network, but the extent of environmental damage was not fully mapped. Besides waste material, the main geochemical media (rocks, ores, soil, river sediment, surface and groundwater) were therefore sampled and analyzed, both with laboratory and field techniques where possible.

\subsection{Sampling strategy, conventional field methods and laboratory analyses}

Surface and groundwater was sampled at 52 monitoring points, including private and public groundwater boreholes, open pit lake, water drainage from the wastes piles and the tailing dumps, 7 newly installed groundwater wells nearby the processing plant area (Figures $2 \& 3$ ) and the main stream water from Kirkalon and Eirini brooks, were performed in regular periods during 2005-2007. Prior to water sampling, temperature, $\mathrm{pH}$, electrical conductivity (EC) were measured on site with portable instruments. Major elements in water were analyzed on raw unfiltered samples by wet chemical methods, mostly according to ASTM standards. Samples for multielement analysis were, on site, filtered at $0.45 \mu \mathrm{m}$ and preserved using ultra-pure $\mathrm{HNO}_{3}$ in $250 \mathrm{ml}$ polyethylene bottles. Trace elements were analyzed by ICP-MS (ASTM D5673:2003). Flow data were obtained on profiled sections using velocity measurements with a rotating element current meter (Romaidis, 2007).

Solid samples were analyzed by a combination of ICP/AES and ICP/MS after aqua regia digestion.

\subsection{Multiparametric probe for in-situ measurement of physico-chemical parameters}

A multiparametric probe with depth sensor (Idronaut Ocean Seven 302) was used to perform chemical diagraphies of water wells $\left(\mathrm{pH}\right.$, temperature, conductivity, Eh, dissolved $\mathrm{O}_{2}$ ) (Lemière $\&$ Crouzet, 2006).

\subsection{Anodic stripping voltammetry for on-site measurement of metals in water}

Metal concentrations in water were determined near the site by SWASV (Square Wave Anodic Stripping Voltammetry). Disposable printed microsensors (Palchetti et al., 2005) connected to a handheld instrument (PalmSens) allow a lower limit of quantification of $5 \mu \mathrm{g} / \mathrm{L}$ for $\mathrm{Cu}$, and limits for $\mathrm{Cd}$ and $\mathrm{Pb}$ close to $2 \mu \mathrm{g} / \mathrm{L}$. Validation was done within the framework of the European project SWIFT-WFD (SSPI-CT-2003-502492). The short distance allowed sample collection on demand. All samples were analysed on the day of collection or the next day (Lemière \& Crouzet, 2006). 


\subsection{Field portable X-ray fluorescence (FPXRF) for on-site measurement of metals in solids}

The FPXRF unit used for this mission was a NITONTM XLt792WY equipped with a X-ray tube (35 $\mathrm{kV}), \mathrm{Mo}$ and $\mathrm{Cu}$ filters allowing the analysis of 22 elements (Mn, Fe, Co, Ni, Cu, Zn, As, Se, Pb, Hg, $\mathrm{Rb}, \mathrm{Sr}, \mathrm{Cd}, \mathrm{Ag}, \mathrm{Sn}, \mathrm{Sb} ; \mathrm{Cr}, \mathrm{V}, \mathrm{Ti}, \mathrm{Sc}, \mathrm{Ca}$ and $\mathrm{K}$ ) in optimum matrix conditions (Lemière \& Laperche, 2006). It was selected for its analytical performance and its suitability to harsh field conditions.

The FPXRF unit was used either a) directly in contact with the soil, sediment or rock target, b) on-site on a roughly homogenised soil or sediment sample, or c) in a near-site location where sample drying, sieving and milling is possible in order to allow sample preparation as close as possible to laboratory conditions. Methods a) and b) are suitable for target identification and sample selection while method c) is required for quantitative results (US-EPA, 1998).

\subsection{AMD potential evaluation}

Acid drainage potential was assessed using the EPA Toxicity Characteristic Leaching Procedure (TCLP), which is designed to determine the mobility of both organic and inorganic analytes present in liquid, solid, and multiphasic wastes, and the Acid-Base Accounting (ABA) test. The latter is a screening procedure whereby the acid-neutralizing potential (ANP) and acid-generating potential (AGP) of rocks, ore, mine waste, and tailing samples are determined. The difference, net neutralizing potential (NNP), and the ratio of neutralizing potential (NPR) were calculated (CINAR and NTUA, 2007, Papassiopi et al., 2009, and Triantafyllidis et al., 2007) in order to assess the acid-generation potential.

\subsection{Data interpretation}

Geochemical data were interpreted with the support of the PHREEQC model and geochemical maps were drawn using ArcGISTM. This provided a sound basis for the elaboration of conceptual models of pollutant transfer from the identified sources, including waste piles, towards potential receptors. The definition of a monitoring network is thus based on locating critical points along preferential transfer pathways, taking into account the actual geochemical processes such as neutralization, precipitation or dissolution.

\section{RESULTS AND DISCUSSION}

\subsection{Site topology and inventory of contaminants}

The former mine (underground galleries and open pit) is located in a narrow valley in an area of low mountains (Fig. 2). Base metals ores were extracted by underground mining and later by open cast mining at Kirki. Open pit exploitation took place at an elevation of +430 to $+345 \mathrm{~m}$ above sea level (Romaidis 2007; Triadafylidis and Skarpelis 2006). Open pit has an ellipsoid shape and covers a total surface area of $-4700 \mathrm{~m}^{2}$. A small lake, with a depth varying between 2 and 8 meters, fills the pit with water from rainfall and drainage (Liakopoulos 2009; Papassiopi and al 2009). Overflow occurs after heavy rains. Ferrous oxide precipitation occurs on the edge of the pit and along the overflow.

A total amount of 252.000 ton raw ore was extracted during 1973 to 1992. Extraction waste, including barren rock, low grade ore and some high grade ore, was stored as unmanaged piles in the immediate vicinity of the open pit, on the downstream course of drainage water (Figs $2 \& 4$ ). Wastes piles are currently exposed to weathering processes that lead to the dissolution of sulphide and gague minerals, the formation of efflorescences and crusts of sulphates such as alunite and natralunite (Liakopoulos 2009) as well as AMD. The total lack of any vegetation and soil coverage on the sulphidic waste piles, increases erosion rates. Both sheet and gully erosion are so intense that fine grained material, including sulphides and sulphates, is washed away by rain storms. 
Ores were beneficiated by flotation in a plant located $5 \mathrm{~km}$ south of the mine. A typical $\mathrm{Zn}$ concentrate composition was (in wt \%): Zn 50; Pb 1.5; Ag 0.012; As 0.12; Sb 0.02; Bi 0.01; Cd 0.60; Fe, 7.8; $\mathrm{S}$ total, 26.1 ( $\mathrm{S}$ as $\mathrm{SO}_{4}, 3.0$ ); $\mathrm{Cu}, 0.3 ; \mathrm{SiO}_{2}, 1.7 ; \mathrm{Al}_{2} \mathrm{O}_{3}, 1.0$; whereas a typical $\mathrm{Pb}$ concentrate composition was (in wt \%): $\mathrm{Pb} 55 ; \mathrm{Zn} \mathrm{5;} \mathrm{Ag}$ 0.07; Cu 2,5; As 1.3; Sb 0.33; Bi 0.95 and total S 17 (Michael \& Exioglou 2003). Processing wastes, which are fine-grained tailings (ore flotation residues), were disposed of, in 8 basins around the plant, near the course of the Kirkalon and Eirini River (Figure 3) (Liakopoulos 2009; Lemiere et al. 2009). The construction of the dams was initially performed by using uncompacted soil material, sand and conglomerates, arising from the neighbourhood talus cone and also from the excavation of the pits. Direct deposition of mud, in order to increase the height of the embankments, is suspected in most of the tailings ponds (Michael \& Dimadis 2006b; Liakopoulos 2009; Loupassakis \& Konstantopoulou 2009). The maximum height of the embankments varies from 5 to $10 \mathrm{~m}$. The area of the tailing ponds varies from $400 \mathrm{~m}^{2}$ to $8,000 \mathrm{~m}^{2}$, and the exact volume of their contents cannot be established without drilling or geophysical investigations (Loupassakis \& Konstantopoulou 2009). A tailings thickness of 2.60 to $3.25 \mathrm{~m}$ was measured in dam $\mathrm{n}^{\circ} 4$, by using sampling drill hole equipment (Liakopoulos 2009). These tailings present a constant risk from physical instability (Konstantopoulou \& Loupasakis, 2007; Loupasakis \& Konstantopoulou, 2009) and spillage, with subsequent impacts on the surrounding rivers, soils and groundwater (Figure 5) (Liakopoulos 2009)

Tailings contain lower but significant contents of ore elements $(\mathrm{Cu}, \mathrm{Pb}, \mathrm{Zn}, \mathrm{Ag}, \mathrm{S})$ and may contain higher contents of unrecovered elements (Fe, Mn, Cd, Cr, Ni).

Contaminants from the mine were identified from ore samples and from open pit pond water; they comprise $\mathrm{Cu}, \mathrm{Zn}, \mathrm{As}, \mathrm{Pb}, \mathrm{Cd}, \mathrm{Ni}$, $\mathrm{Co}$ along with anomalous levels of $\mathrm{Mn}, \mathrm{Fe}$, and sulphate. Contaminants from the plant were identified from tailings samples and from water; they comprise $\mathrm{Cu}, \mathrm{Zn}, \mathrm{Pb}, \mathrm{Cd}$, and anomalous levels of $\mathrm{Mn}, \mathrm{Fe}$, and sulphate. These two contamination patterns, similar in essence to geochemical signatures, can be distinguished by the differential mobility of $\mathrm{Zn}$, $\mathrm{Cu}$ and $\mathrm{Pb}$.

\subsection{Inventory and hierarchisation of contamination sources}

The Kirki mine extraction wastes are strongly heterogeneous geological materials, and the particle sizes range from clay size to boulder size fragments. At the mine site (Figure 2), they include ore (observable at mine site exposures), extraction waste ("steriles", disposed of as waste dumps), and drainage sediment. The total surface of the operations area disturbed by mining, reaches $77.000 \mathrm{~m}^{2}$ (Papassiopi et al. 2009) whereas the total volume of the waste pile was estimated by Michael $\&$ Dimadis (2006b) at $90.000 \mathrm{~m}^{3}$ (Figures $2 \& 4$ ).

Water percolating waste dumps and open pit pond water show also very high concentrations of contaminants (Table 1), along with strong acidity ( $\mathrm{pH} 1$ to 4 ) and salinity (especially sulphate, Table 1). This is a typical acid mine drainage (AMD) situation. Mine area drainage was allowed to flow freely over and through the piles (Figure 4). The bottom drainage of waste piles flows freely into the Kirkalon brook.

The majority of water data derived from the Kirki mine waste area, are in the "moderate acid/extreme metals" to "near neutral/extreme metals" section of the Ficklin plot (Ficklin et al. 1992) shown in Figure 6, as well as the data from drainage waters of the tailings dams. Waters from open pit lake plot in the "high acid/extreme metals" section, whereas data from underground mine gallery runoff (K4) and from the shallow aquifer, near to the plant, plots to "near neutral/extreme - high metal" section. The distribution of these high to extreme metal concentrations in acid as well as near neutral drainage waters implies that AMD is taking place at Kirki. 
Tailings material contains significant contents from the environmentally important elements As, Cd, $\mathrm{Cu}, \mathrm{Pb}, \mathrm{Zn}, \mathrm{Mn}, \mathrm{Cr}, \mathrm{Ni}$ and $\mathrm{S}$ (Table 1). This reflects the complex ore paragenesis (Michael et al. 1989). Along the main drill hole profiles (Figure 3 : drill holes G4-1 to G4-4), the maximum concentrations (in $\mathrm{mg} \mathrm{kg}^{-1}$ ) for the elements listed before are: arsenic 810; cadmium 212; copper 814; lead 13748 (1,37 \%); zinc 19142 (1,9\%); manganese 8947; Cr 210; nickel 159 and sulphur 4.17\% (Liakopoulos 2009).

According to Papassiopi et al., (2009), the Neutralization Potential to Acid Potential (NP/AP) ratio of the ABA test, varies from 0.0 to 1.6 for extraction waste, implying a minor to significant level of AMD risk, while for tailings the ratio varies between 0.0 and 0.2 , implying a minor level of AMD risk only.

The predominant importance of mine waste results from a) its larger volume (estimated $170000 \mathrm{~m}^{3}$, about 400000 ton, plus an extra $15700 \mathrm{~m}^{3}$ of crushed ore near the mill, about 40000 ton), b) its permanent exposure to AMD which increases metal solubility by 1 to 3 orders of magnitude (Garralón et al., 1999). On the opposite, ore processing waste (tailings) represent a lower quantity (estimated $36500 \mathrm{~m}^{3}$, about 80000 ton), and they are less exposed to AMD. However, they represent a significant contamination source in solid form, as unmaintained tailings dams failure allow metalliferous tailings to be released to the Eirini river through breaches (Figure 5).

Contaminant mobility and bioavailability is higher in tailings than in ores or rocks (Concas et al., 2006). It may be further increased by the local climatic and hydrologic conditions, favouring oxidation and flushing through hydration-dehydration cycles (Kovacs et al., 2006).

Moreover, the migration and dispersion of trace metal elements such as, cadmium, lead, zinc, manganese, copper, happens also due to erosion and mine run-off phenomena during heavy rainfall events, and due to the emission of air-borne particles during dry and windy periods.

Other waste comprises abandoned process reagents such as : Xanthate, sodium sulphide $\left(\mathrm{Na}_{2} \mathrm{~S}\right)$, zinc sulphate heptahydrate $\left(\mathrm{ZnSO}_{4} .7 \mathrm{H}_{2} \mathrm{O}\right)$, disodium metasilicate $\left(\mathrm{Na}_{2} \mathrm{SiO}_{3}\right)$, disodium carbonate $\left(\mathrm{Na}_{2} \mathrm{CO}_{3}\right)$, cyanide compounds like 2-4 toluene diisocyanate (Liakopoulos 2009), and possibly $\mathrm{NaCN}$ (Arikas et al. 2007, Lemiere et al 2009) plus flotation cake, ore concentrates, and engine oil. Processing reagents and concentrates constitute an immediate source for contamination, due to their derelict condition, but most of it would no longer constitute a source once the heaps and barrels are removed.

\subsection{Mapping of contamination receptors}

Analyses on the above mentioned contaminants in river water and sediments showed that mine and plant-related pollutions have significant impacts downstream until reaching the sea, $25 \mathrm{~km}$ from the mine site (Figure 7). The investigation for impacts in the catchment was much more detailed due to the use of field methods (FPXRF and voltammetry), and the option of immediate results allowed to refine the sampling plan. The most significant points and samples were subjected then to laboratory analyses.

No permanent habitation, cultivated area or water resource use was observed between the mine site and the Eirini river, which collects all the site drainage (Figure 8). Local farming and grazing was observed nearby the former plant site, on the Eirini alluvial flats. Contamination was observed in soil and shallow groundwater (Table 1, Figure 9).

Ground water monitoring investigations revealed that uncontrolled infiltration of the surface water along the main pollution sources of the plant area (tailings ponds, plant facilities), allows pollutants to contaminate shallow groundwater (Liakopoulos 2009).

Water contamination occurs in surface and shallow groundwater (aquifer) in a large area including the Kirkalon valley, the vicinity of the plant and in the Eirini valley some hundred meters downstream the processing plant, making it unfit for agricultural use due to surface and groundwater contamination. 
However, the main potential receptors are located further downstream the Eirini valley: the agricultural areas of the littoral plain, and the underlying groundwater resources (Figure 7). The contaminated Eirini water may easily infiltrate through the karstic system and contribute to groundwater recharge.

The concentrations of toxic metals in surface and ground waters varied widely at the study area from point to point (Table 1) but also from season to season (Liakopoulos, 2009). High concentrations of $\mathrm{Zn}, \mathrm{Mn}, \mathrm{Cd}, \mathrm{Cu}, \mathrm{Ni}$ and $\mathrm{Pb}$ were observed in waters, especially from the mine and the plant area (Fig. 10).

Based on the available data metal levels are nevertheless relatively low, below the Greek National drinking water standards, in the Eirini river, as well as at the Alexandroupolis water supply aquifers (Figure 10, Table 1), but careful monitoring of ore elements should be continued.

It is essential to guarantee a suitable water quality for the future. For this the littoral groundwater resources must be regularly monitored at least for $\mathrm{As}, \mathrm{Cd}, \mathrm{Cu}, \mathrm{Pb}$ and $\mathrm{Zn}$ with high sensitivity methods, in order to warn if contamination by mine-derived pollutants builds up in the aquifers. If contamination is found to be increasing, a community alert system would be necessary.

Last, it should be remembered that contaminated surface water and carried sediment end up in the Aegean sea, with possible impacts on the marine life, not yet documented.

Stream sediments, contamination occur in high levels in all Kirkalon stream sediments and drops gradually downstream the plant in the first part of the Eirini course (Figure 11). The migration of contaminated sediment is controlled by the existence of two dams along the course of the Kirkalon brook.

\subsection{Conceptual models for contamination from waste sources}

At the mine site, the main contamination process is the exposure of oxidised metal sulphide and sulphate to rainfall and infiltration water. It occurs in the old mine galleries (runoff water), in the open pit (water pool) and in the extraction waste pile, where it is most efficient due to the fragmented state of rocks. This is reflected by the lower $\mathrm{pH}$ of waste dump drainage. Dissolved $\mathrm{Cu}, \mathrm{Zn}, \mathrm{Pb}, \mathrm{As}$ and $\mathrm{Cd}$ are released in solute form to the mine brook, where neutralisation occurs mainly between the waste pile bottom and the dam (Figure 8). Metals movement continues downstream in solid form, as precipitate or sediment. Mine emissions reach the Eirini river near the plant site.

At the plant site, waste leaching by rainfall is also active on ore stockpiles, on concentrate and on tailings. However, contaminant concentrations in solute form are much lower due to the near neutral $\mathrm{pH}$ values and absence of widespread AMD. They are nevertheless high enough to affect soil and shallow groundwater at the plant site (Figure 9), though the exact contribution of mine pollution and of plant pollution cannot be specified. The most important mass of contaminants is released in solid form, as direct tailings discharges to the river during storm rains (Figure 5).

Most of the contaminants released to the Eirini river, both from mine and plant origin, are in solid form. They can be flushed to the sea as such, but they may also accumulate in sediment pools and release $\mathrm{Cu}, \mathrm{Zn}, \mathrm{Pb}, \mathrm{As}$ and $\mathrm{Cd}$ to the river water by redissolution, allowing further contamination of surface and groundwater resources (Figure 7).

The gradual decrease of the metal concentrations in solution, from the source points to the potential targets is due to (1) neutralisation of acid waters at runoff, (2) dilution by unaffected stream waters, both increasing $\mathrm{pH}$ values, and (3) subsequent precipitation of Fe and Al-phases (Liakopoulos 2009). 


\subsection{Waste classification, mitigation and remediation options}

Mining waste present at the Kirki mine and plant sites comprises all of the categories mentioned before:

A - Extraction wastes mainly constituted of silicoaluminate rocks with iron and base metal sulphides, which is a major source for AMD (seepage $\mathrm{pH} 1$ to 2 ). It is open to percolation, hence the only mitigation option is accelerated neutralisation of its bottom drainage, to prevent acid water to accelerate heavy metals and metalloids transfer to the environment. Options for remediation are focused on water and drainage control. The construction of diversion channels for the main upstream brooks (e.g. Kirkalon and tributaries), in order to minimize direct rain water percolation into the waste piles, is of first priority and should be investigated in detail. Downstream drainage neutralisation might be achieved by filling the existing dam (Figure 8) with crushed limestone. However, this will leave the brook exposed to metal contamination. It is thus necessary to prevent immediately any use of its water (drinking, cattle breeding or irrigation), and to monitor water quality at the junction with the Eirini river;

B - Tailings, mainly constituted of rock particles, with iron and bioavailable base metals, including minor but significant amounts of toxic elements like $\mathrm{Cd}$ and, As (EU, 2006b). They may be also released in solid form towards surface water through uncontrolled dam failure. The most urgent remediation step is thus dams consolidation. The remaining flotation mud found inside the processing plant, the dispersed mud around the tailing dams area and the river sediments from Kirkalon and Eirini streams, in the immediate vicinity of the existing tailings dams, should be carefully removed and collected for storage into one of the existing tailing dams;

$\mathrm{C}$-Leftover processing reagents such as cyanide or Xanthate, as well as abandoned, in open air, $\mathrm{Pb}-\mathrm{Zn}$ concentrates and other ore processing wastes. It represents immediate and severe chemical hazards, localised in a few spots, and has to be remediated urgently by careful removal, as the recent cleaning operations completed only a very partial removal.

Before any remediation measure takes place, a detailed risk evaluation study should be initiated. A careful planning of mitigation actions is required, as waste removal and confinement may bring efficient options, while improperly managed AMD may ruin any remediation efforts and lead to continuous pollution (Unruh et al., 2009).

Emissions monitoring should be performed by regular analyses of drainage, brook and river water downstream from mine until Alexandroupolis town. It should be complemented by receptor monitoring of groundwater and soil near the plant and in the Alexandroupolis area (Lemière $\&$ Crouzet, 2006; Lemière \& Laperche 2006).

A community alert system should provide early information on emission peaks for $\mathrm{Cd}$ and other metals in the river water. This may be achieved by a network of rainfall recorders, $\mathrm{pH}$-conductivity probes and flow sensors. 


\section{CONCLUSIONS}

Two main types of abandoned mine waste are present at the Kirki former mining and ore processing site, and they currently present major environmental hazards for water and soil resources in the Alexandroupolis region, especially cadmium and arsenic contamination.

Mine extraction waste contributes through acid mine drainage (AMD) and leaching, while ore processing waste (tailings) is also released in solid form. The former cannot be directly remediated economically as such and the resulting water contamination has to be mitigated in the drainage itself. Water contamination may be reduced by neutralisation, preferably with large scale passive methods such as crushed limestone beds. The latter can be remediated through proper dam management and confinement. Other options such as mine backfill are available and would require adequate risk evaluation.

The main potential impacts are the contamination of surface water, soil and groundwater downstream the plant facilities, especially littoral groundwater used for drinking and irrigation purposes. This may require a community alert network if the present contamination of the so far unused surface water affects in the future the groundwater resources of the littoral plain.

The identification of the contamination sources (waste) and targets (water, soil), the definition of pathways and conceptual models, and the design of a monitoring network were significantly easier and more efficient due to the availability of field methods (e.g. FPXRF, voltammetry). This strategy does not replace, but improve, the traditional approach with laboratory analyses, and it helped to keep costs under control.

\section{ACKNOWLEDGMENTS}

Present study is part of the work that IGME has accomplished in the framework of project 65231 with the support of EU structural funds (3rd Community support framework, Ministry of Development, Operational Programme "Competitiveness" (O.P.C.), project 65231). The constructive comments of two anonymous reviewers are gratefully acknowledged. Further support was provided by BRGM Research Division. We are grateful to IGME foremen N. Charitos, V. Arvanitidis, I. Chatzopoulos and T. Kyrmizopoulos, for field work. 


\section{REFERENCES}

Arrikas K, Asfahani, N., Nowak, A. \& Goetz, D. (2007). The Kirki mine in Evros Prefecture, NE Greece, and considerations on the environmental impact. Mining and Metallurgical Annals, Mining and Metallurgical Annals $17 \mathrm{Vol} 1-2,21-50$ \& 51-69.

Charbonnier, P. (2001). Management of mining, quarrying and ore-processing waste in the European Union, Final Report to DG ENV on Mining Waste in the EU, BRGM report RP50319-FR.

http://ec.europa.eu/environment/waste/studies/mining/0204finalreportbrgm.pdf (December 10, 2009).

CINAR S.A. \& NTUA (2007). Test results of environmental geochemical characterization of samples from the Kirki mine area. Unpublished IGME internal Report, project 65231.

Concas, A., Ardau, C., Cristini, A., Zuddas, P., \& Cao, G. (2006). Mobility of heavy metals from tailings to stream waters in a mining activity contaminated site. Chemosphere, 63, 244-253.

EU (1991). Council Directive 91/689/EEC of 12 December 1991 on Hazardous Waste. The Council of the European Union.

EU (2006a). Council Directive 2006/21/EC of the European Parliament and of the Council of 15 March 2006 on the management of waste from extractive industries and amending Directive 2004/35/EC (in short: MWD). The Council of the European Union.

EU (2006b). Directive 76/464/EEC of 4 May 1976 on pollution caused by certain dangerous substances discharged into the aquatic environment of the Community (OJ L 129, 18.5.1976, p. 23). Directive as last amended by Directive 2000/60/EC.

Ficklin, W.H., Plumlee, G.S., Smith, K.S., and McHugh, J.B., 1992, Geochemical classification of mine drainages and natural drainages in mineralized areas, in Kharaka, Y.K., and Maest, A.S., eds., Water-rock interaction: Seventh International Symposium on Water-Rock Interaction, Park City, Utah, July 13-18, 1992, Proceedings, v. 1, Rotterdam, A.A. Balkema, p. 381-384..

Garralón, A., Gómez, P., Turrero, M.J., Sánchez, M., \& Melón, A.M. (1999). The geochemical aspects of toxic waters retained in the Entremuros area (Spain). The Science of the Total Environment, $242,27-40$.

JRC (2004). Reference Document on Best Available Techniques for Management of Tailings and Waste-Rock in Mining Activities. Joint Research Centre, European Commission, Sevilla, Spain.

Konstantopoulou, G., \& Loupasakis, C. (2007). Geotechnical stability study of the tailings ponds of the Kirki mine, Evros Prefecture. Unpublished IGME internal Report, IGME-Institute of Geology and Mineral Exploration, Athens.

Kovacs, E., Dubbin, W.E., \& Tamas, J. (2006). Influence of hydrology on heavy metal speciation and mobility in a $\mathrm{Pb}-\mathrm{Zn}$ mine tailing. Environmental Pollution, 141, 310-320.

Lemière, B. \& Crouzet, C. (2006). Test of monitoring tools for mining and industrial environmental applications on the Kirki mining area (Greece) - Phase 2. Unpublished BRGM report RC-55029-FR, 48 p., 2 appendixes.

Lemière B. \& Laperche V. (2006).- Test and feasibility of the implementation of monitoring tools for mining and industrial environmental applications on the Kirki mining area (Greece). Unpublished BRGM report RC-54499-FR, 102 p., 5 appendixes.

Lemiere,B., Laperche, V., Crouzet, C., Lassin, A. , Liakopoulos, A., Michael, C., Drougas, I. \& Romaidis, I., (2009): Geochemical investigations in view of the implementation of a monitoring system at a former base metal mining and ore processing site (Kirki, Thrace, Greece). In Proceedings 
of 3rd AMIREG International Conference (2009): Assessing the Footprint of Resource Utilization and Hazardous Waste Management, Athens, Greece, pp253-257.

Liakopoulos, A. (2009) : Environmental study of the former Kirki mines area. Pollution extension and proposed abatement measures. Unpublished IGME internal Report, IGME-Institute of Geology and Mineral Exploration, Athens, 227p, 2 appendixes.

Loupasakis, C., \& Konstantopoulou, G. (2009). Safety assessment of abandoned tailings ponds: an example from Kirki mines, Greece. Bulletin of Engineering Geology and the Environment, in press.

Michael, C., Constantinides, D., Ashworth, K., Perdikatsis, V., \& Demetriades, A., (1989). The polymetallic ore mineralization of the Kirki area, Alexandroupolis district, Northeast Greece. Geologica Rhodopica, vol. 1.

Michael, K. \& Dimadis, E. (2006a). Geological study of the area around the Kirki beneficiation plant. Unpublished IGME internal Report.

Michael, K. \& Dimadis, E. (2006b). Results of geological mapping in scale 1: 25.000 in the catchment area of "Eirini" stream. Unpublished IGME internal Report.

Michael, K \& Exioglou, D. (2003). Inventory of past mining activities in the Eastern Rodope area. Unpublished IGME internal Report.

Palchetti, I., Laschi, S., \& Mascini M. (2005). Miniaturised stripping-based carbon modified sensor for in field analysis of heavy metals. Analytica Chimica Acta. 530, 61-67.

Papassiopi, N., Mylona, E., Xenidis, A., Paspaliaris, I., Liakopoulos, A., Angellatou, V. \& Drougas, J. (2009). Assessment of major acid generation sources in the mining site of Agios Filippos, Kirki, GR. in: Proceedings of 3rd AMIREG International Conference (2009): Assessing the Footprint of Resource Utilization and Hazardous Waste Management, Athens, Greece, pp333-338.

Rico, M., Benito, G., Salgueiro, A.R., Diez-Herrero, A. \& Pereira H.G. (2008). Reported tailings dam failures - A review of the European incidents in the worldwide context. Journal of Hazardous Materials, 152, 846 - 852 .

Romaidis, I. (2007). Preliminary hydrogeological study of the Kirki mines area. Unpublished IGME internal Report. Institute of Geology and Mineral Exploration, Athens.

Symonds \& COWI (2001). A Study on the Costs of Improving the Management of Mining Waste. Final Report to DG ENV on Mine Waste Costs.

http://ec.europa.eu/environment/waste/studies/mining/mining cost.pdf (December 10, 2009).

Triantafyllidis, S. \& Skarpelis, N. (2006) Mineral formation in an acid pit lake from a high-sulfidation ore deposit: Kirki, NE Greece. Journal of Geochemical Exploration 88, 68- 71.

Triantafyllidis, S., Skarpelis, N. \& Komnitsas, K. (2007) Environmental characterization and geochemistry of Kirki, Thrace, NE Greece, abandoned flotation tailing dumps. Environmental Forensics, 8, 351-359.

Unruh, D.M., Church, S.E., Nimick, D.A., \& Fey, D.L. (2009). Metal contamination and postremediation recovery in the Boulder River watershed, Jefferson County, Montana. Geochemistry: Exploration, Environment, Analysis, 9, 179-199.

US-EPA (1998). EPA Method 6200. Field Portable X-Ray Fluorescence Spectrometry for the determination of Elemental Concentrations in Soil and Sediment. In: "Test Methods for Evaluating Solid Waste", Third Edition (SW-846). With promulgated revisions. U.S. Environmental Protection Agency (EPA), http://www.epa.gov/osw/hazard/testmethods/sw846/pdfs/6200.pdf (December 10, 2009). 
FIGURES \& TABLES

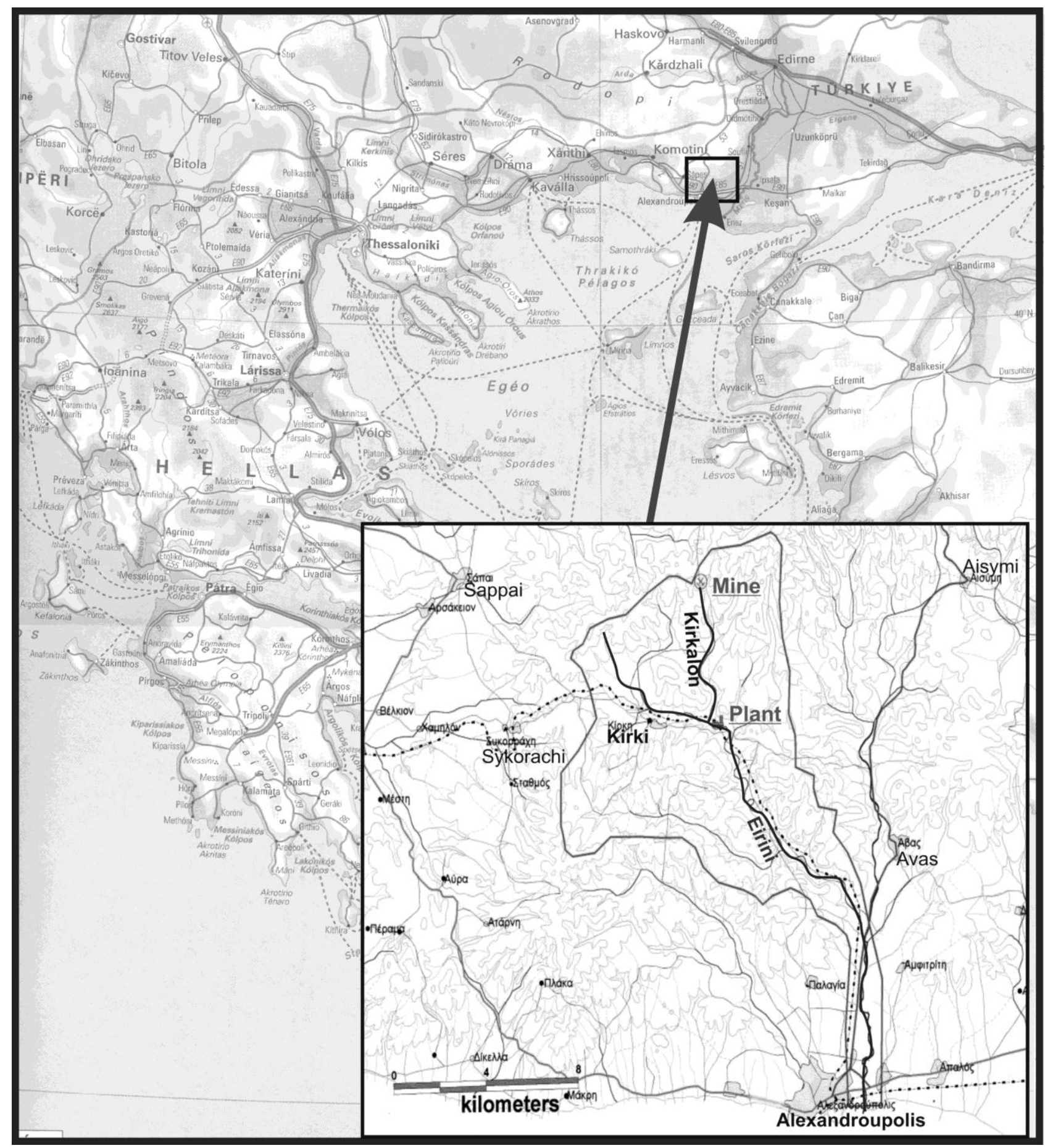

Figure 1 : The Kirki mine area. 


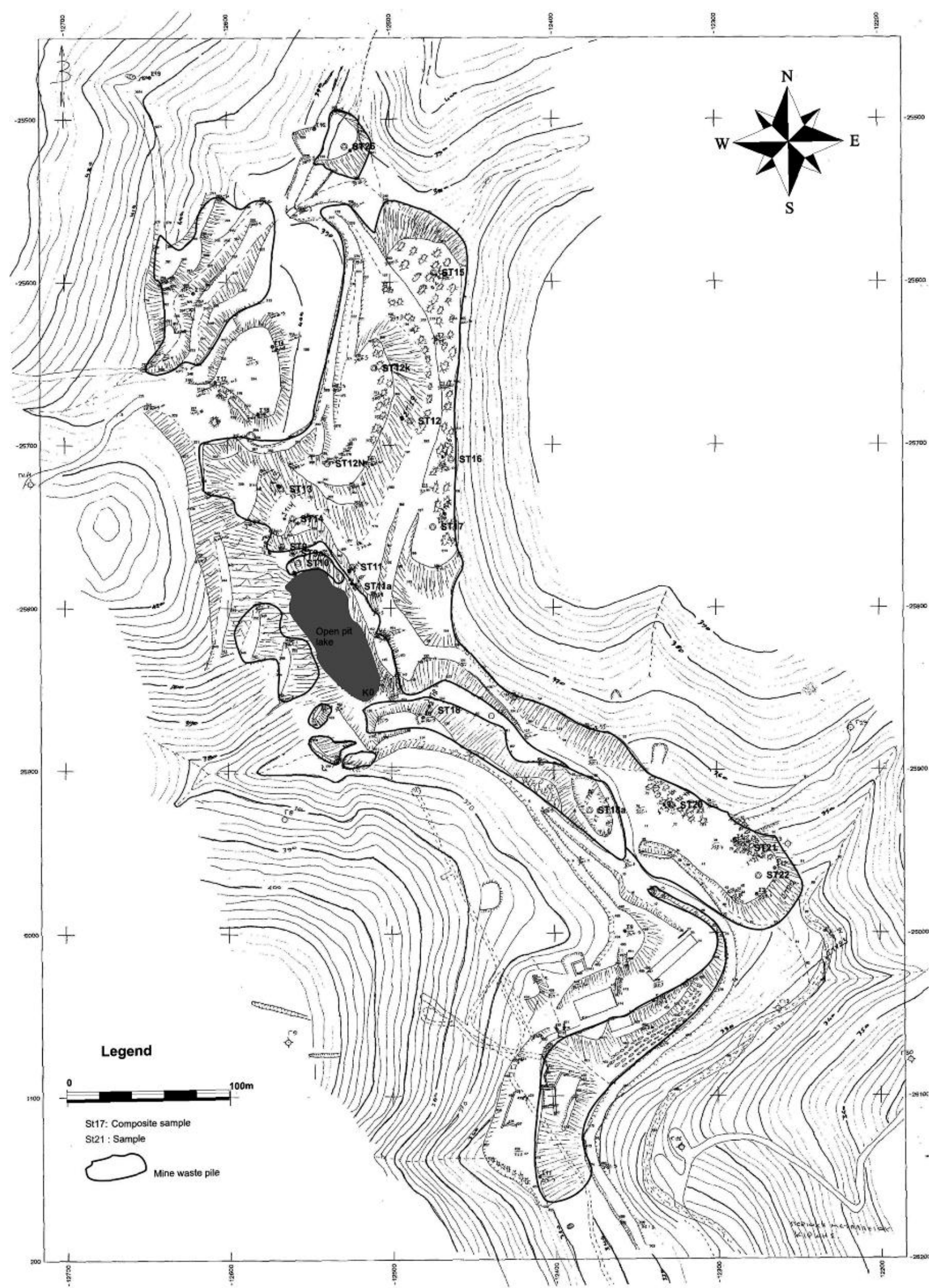

Figure 2. Total area disturbed by mining operations. The open pit lake and the extraction waste piles are delineated (Modified from Liakopoulos 2009). 


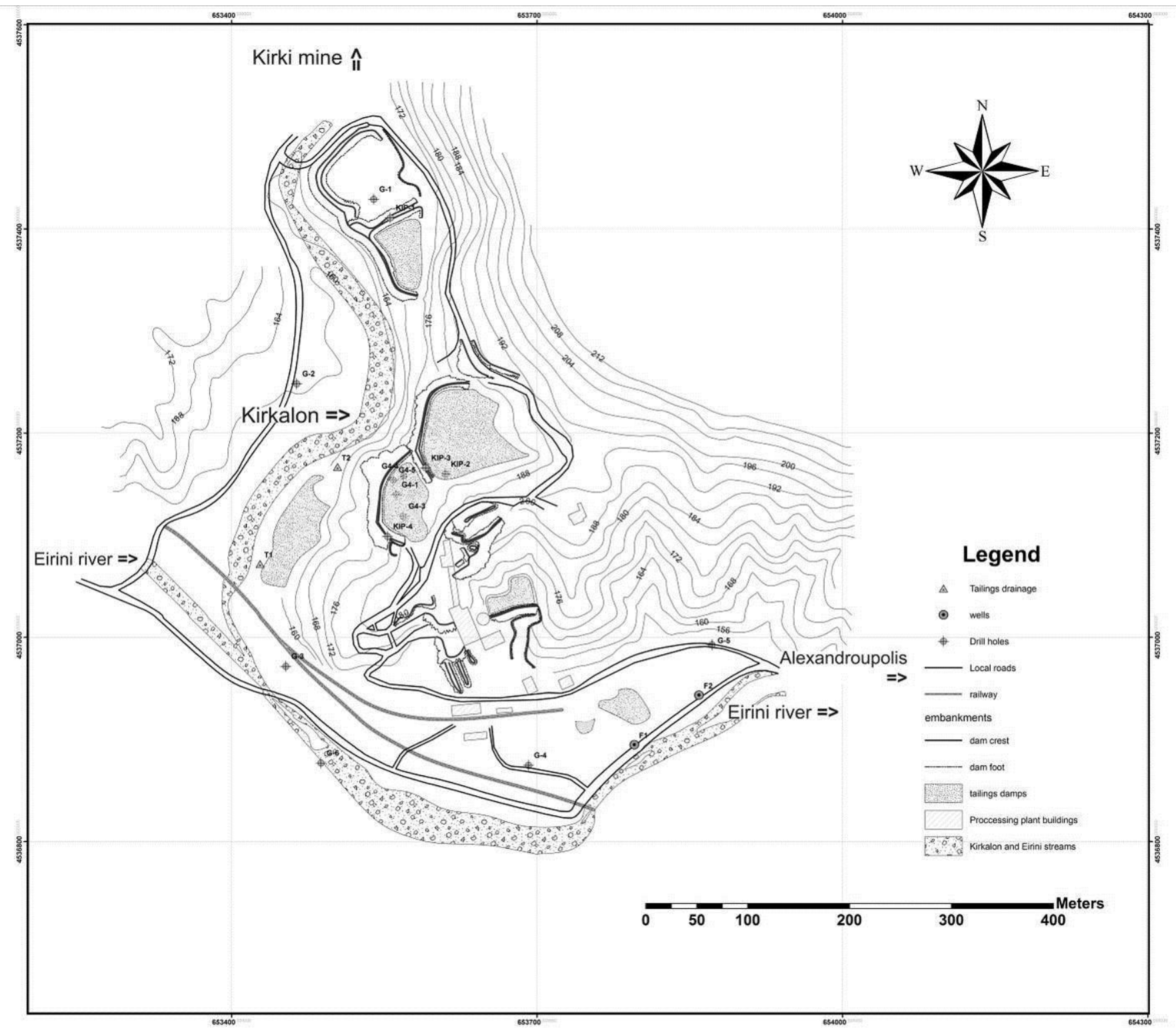

Figure 3. Map of Kirki processing plant area, indicating the position of the tailing dams. Modified from Michael and Dimadis (2006). 


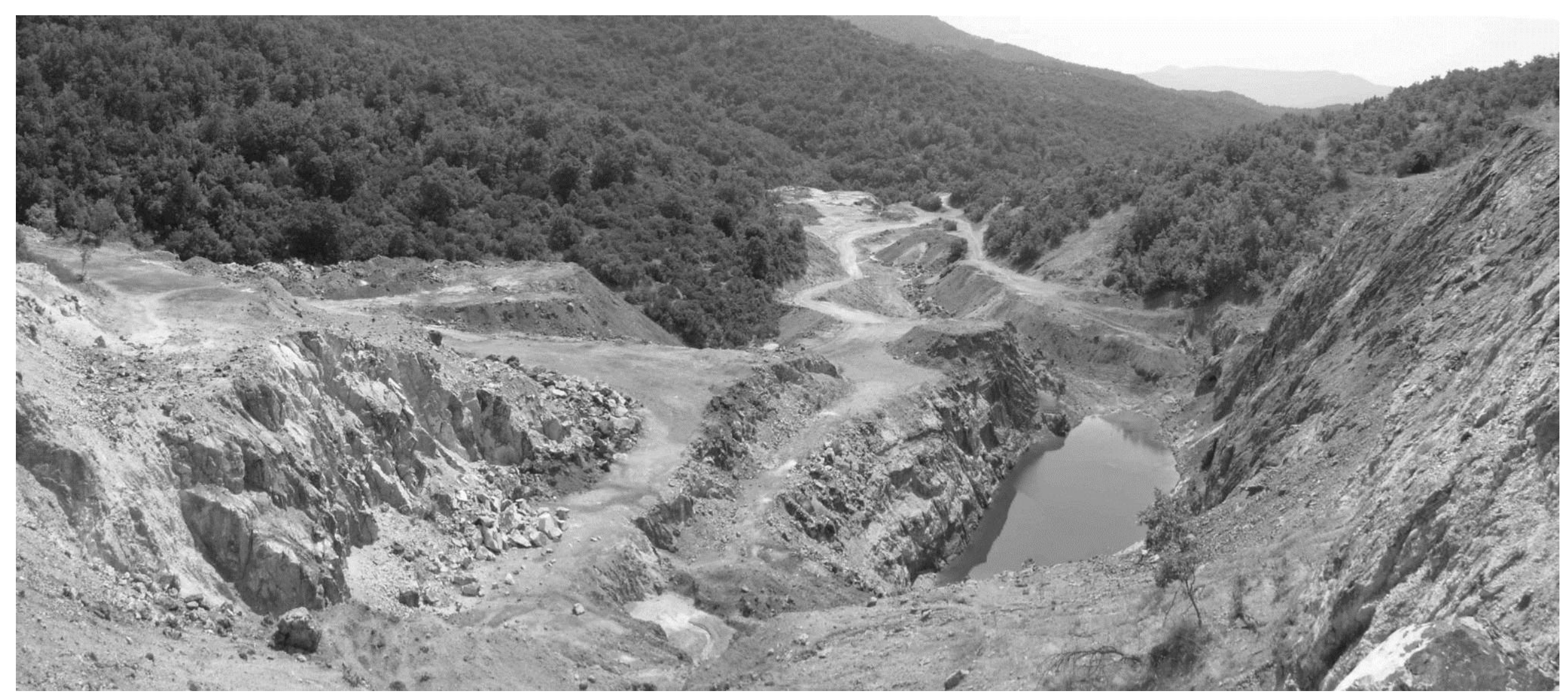

Figure 4. General view of the open pit mine area. Mining waste dumped downstream and waste heap drainage escaping towards the brook. 


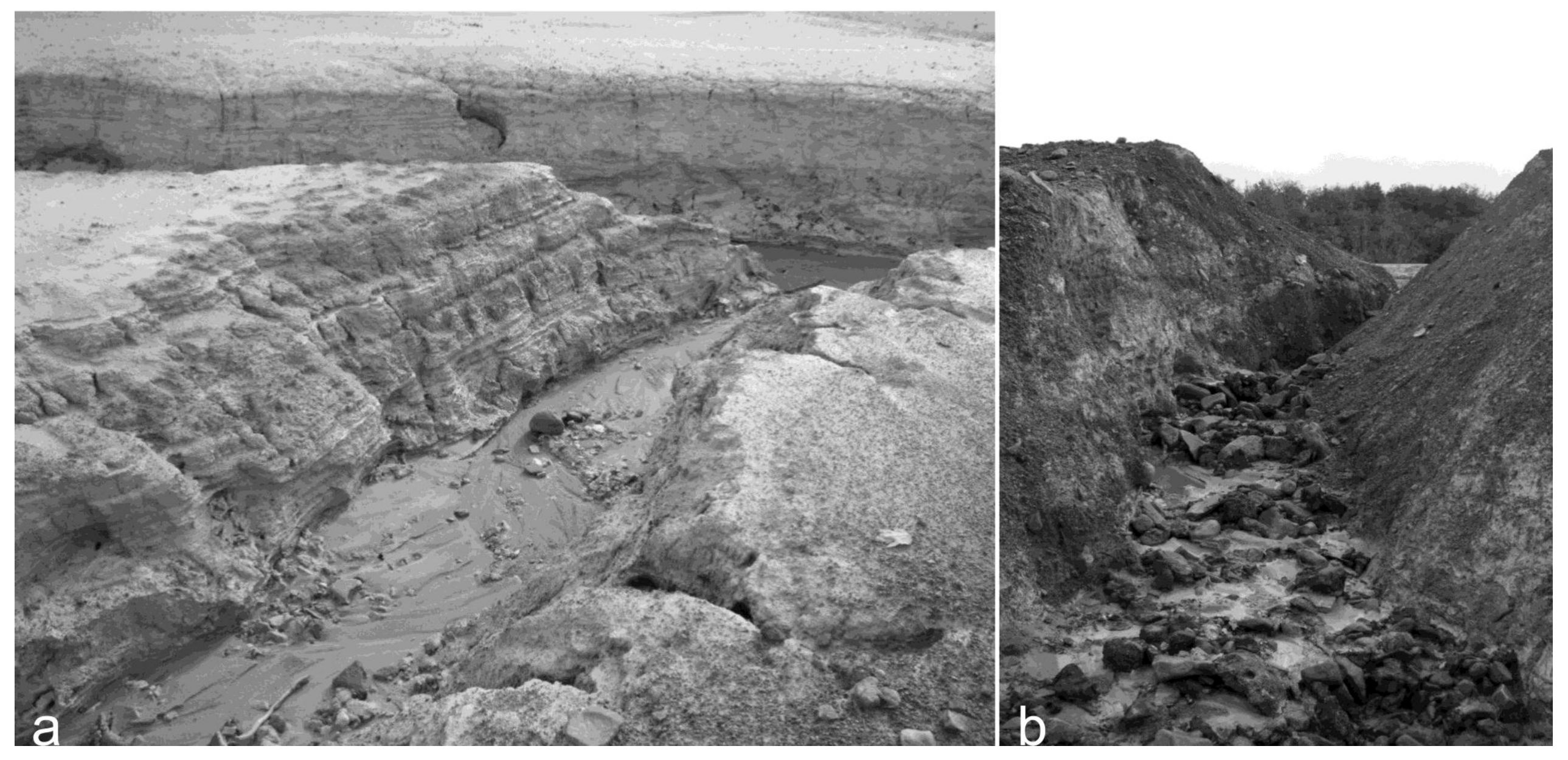

Figure 5. Deep gully tailing dam erosion (a). Process waste (tailing) escaping through dam breach towards the river (b). 


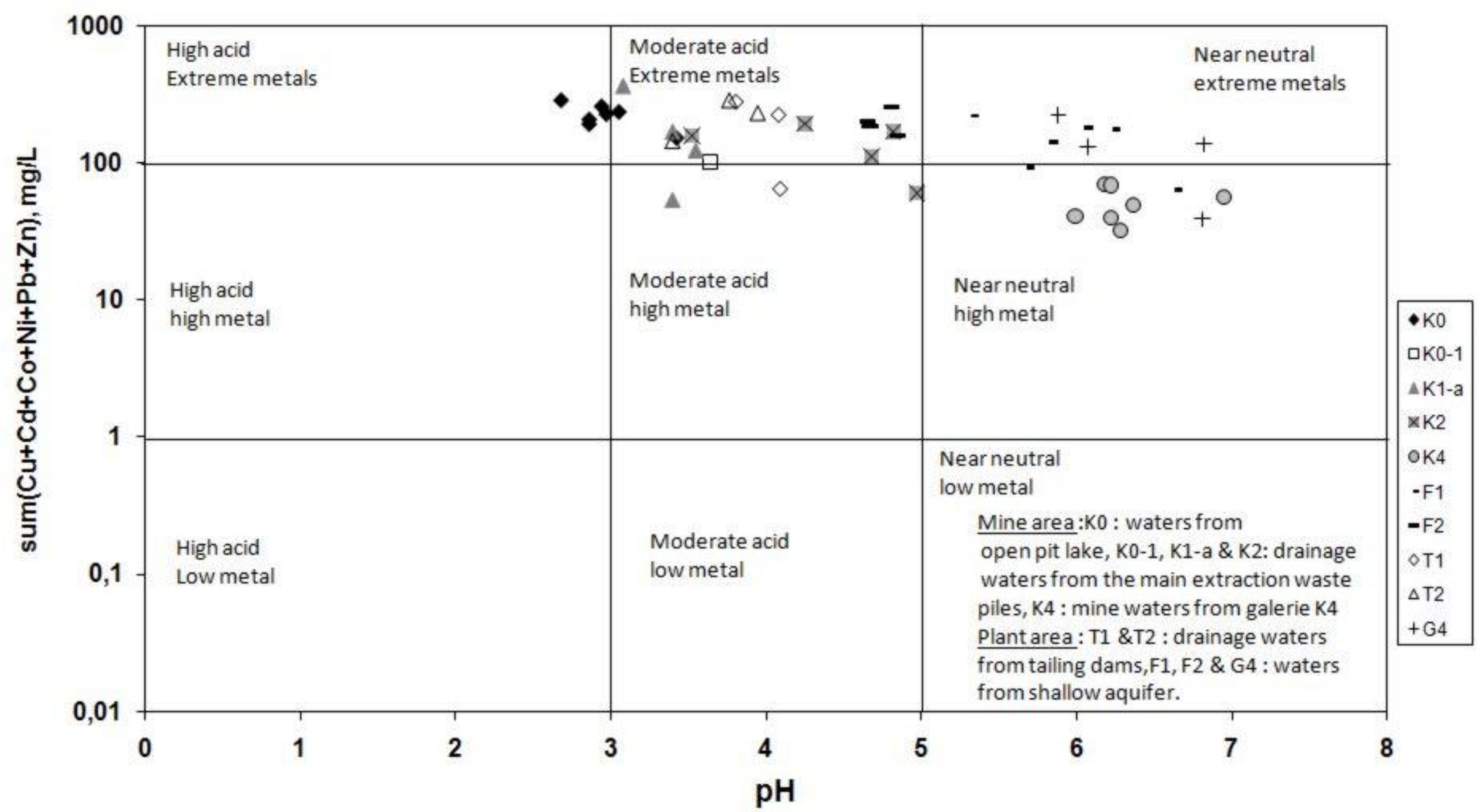

Figure 6 : Ficklin diagrams of $\mathrm{pH}$ versus dissolved metal content in water samples collected from the Kirki Mine and the Kirki plant area. 
Mine \&

plant site

Eirini river

Alexandroupolis area water supply

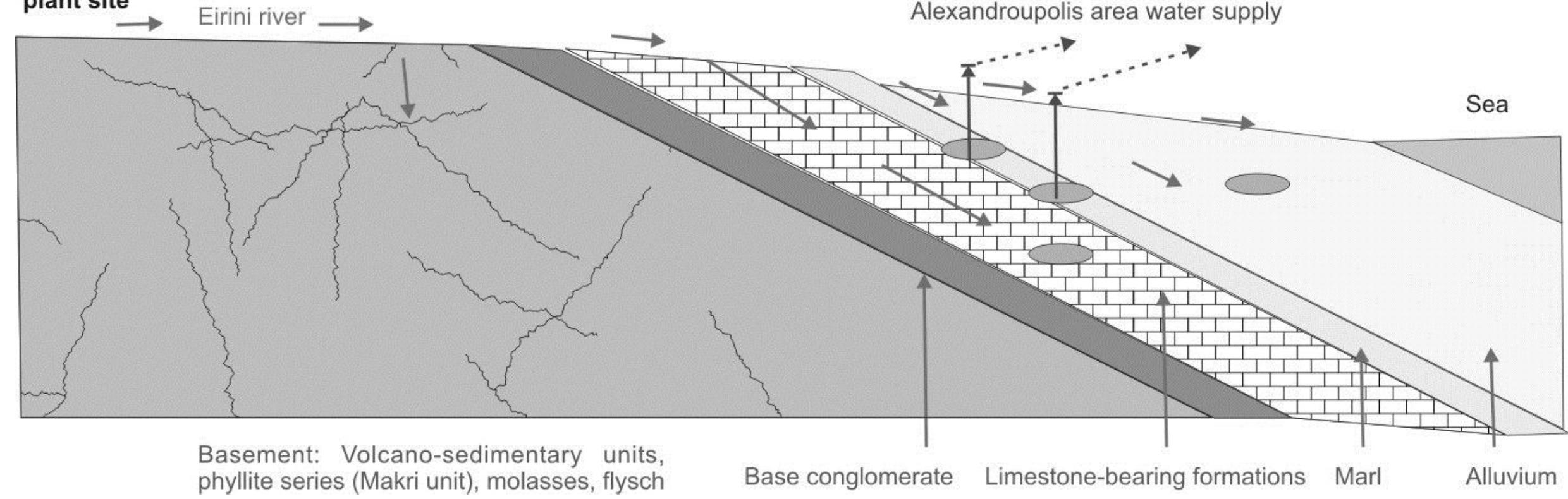

Figure 7. Conceptual model of receptor contamination by the mine and plant waste. 


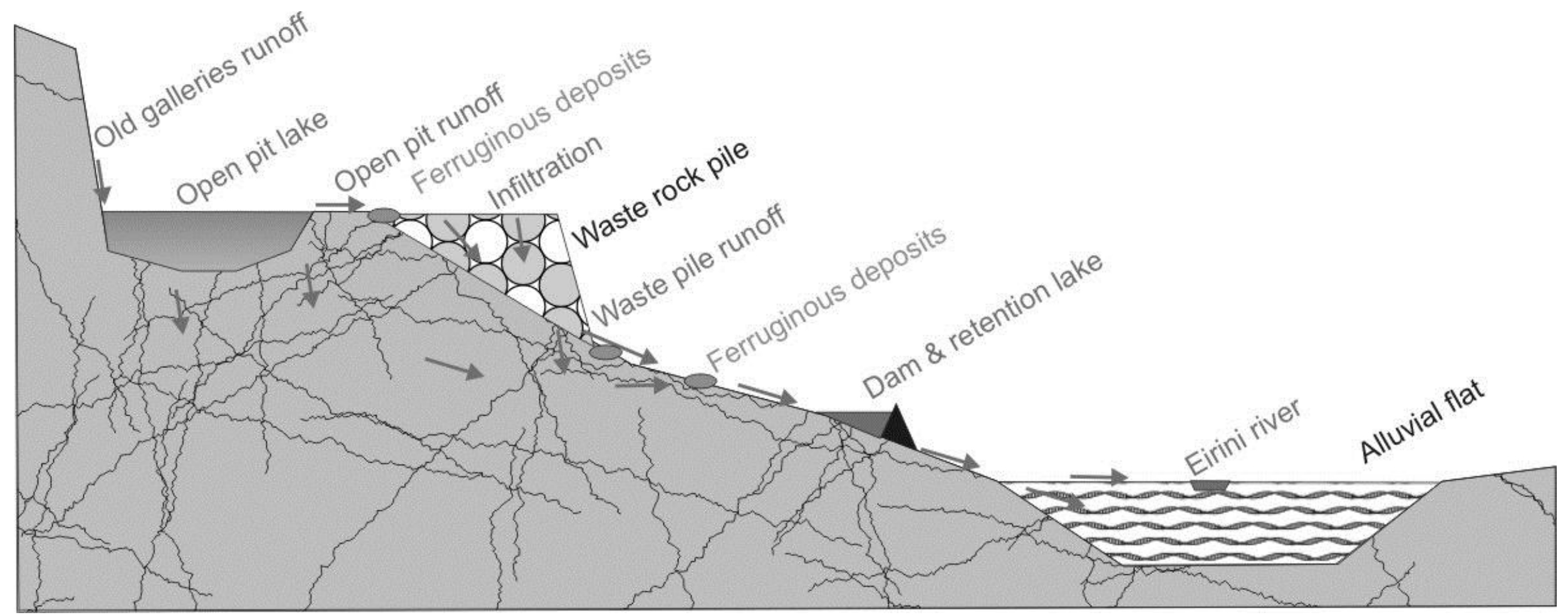

Figure 8. Conceptual model of contaminant emission by mine waste. 


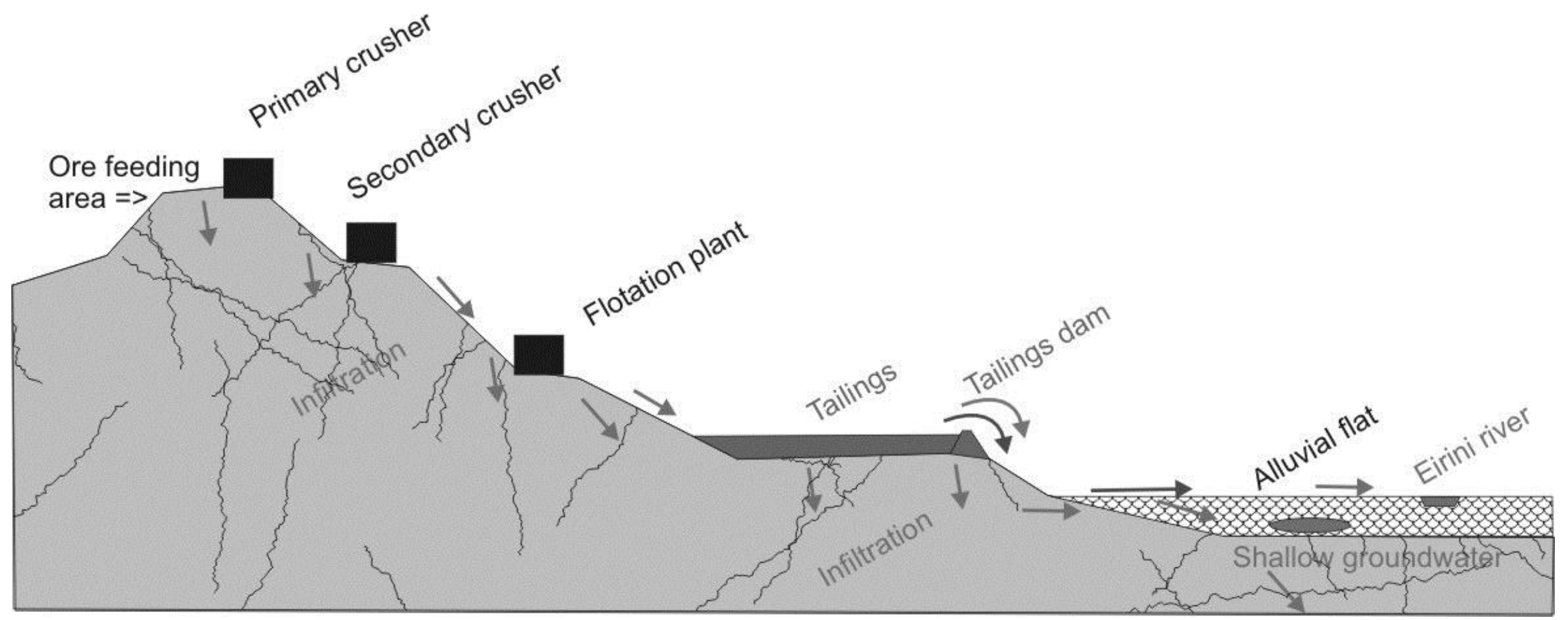

Figure 9. Conceptual model of contaminant emission by ore processing waste. 
Table 1. Typical contents in heavy metals and metalloids for investigated locations

\begin{tabular}{|c|c|c|c|c|c|c|c|c|c|c|c|}
\hline & Unit & $\mathrm{Cu}$ & $\mathrm{Pb}$ & $\mathrm{Zn}$ & $\mathrm{Cd}$ & As & $\mathrm{Ni}$ & $\mathrm{Mn}$ & $\mathrm{S}$ & $\mathrm{pH}$ & $\begin{array}{l}\text { EC } \\
\mu \mathrm{S} / \mathrm{cm}\end{array}$ \\
\hline \multicolumn{12}{|l|}{ Mine area } \\
\hline Ore (1) & $\mathrm{mg} \mathrm{kg}^{-1}$ & 250000 & 400000 & 90000 & (2) & 20000 & & & $\begin{array}{c}250000 \\
\text { (6) }\end{array}$ & & \\
\hline $\begin{array}{l}\text { Open pit } \\
\text { water }\end{array}$ & $\mu g \mathrm{~L}^{-1}$ & 10550 & 900 & 270000 & 2350 & 6 & 1120 & 82000 & $\begin{array}{c}430000 \\
(7) \\
\end{array}$ & 2.7 & 2160 \\
\hline \multicolumn{12}{|c|}{ Downstream mine waste dumps } \\
\hline $\begin{array}{l}\text { Mine waste } \\
\text { (dump) (1) }\end{array}$ & $\mathrm{mg} \mathrm{kg}^{-1}$ & 700 & 15000 & 2000 & & 1200 & & & $\begin{array}{c}3000 \\
20000 \\
(10)\end{array}$ & & \\
\hline $\begin{array}{l}\text { Mine dump } \\
\text { area }\end{array}$ & $\mathrm{mg} \mathrm{kg}^{-1}$ & 160 & 2700 & 6400 & 45 & 98 & 33 & 3400 & 4600 & & \\
\hline $\begin{array}{l}\text { Waste dump } \\
\text { drainage }\end{array}$ & $\mu g \mathrm{~L}^{-1}$ & 4840 & 640 & 93600 & 1120 & & 864 & 129000 & $\begin{array}{l}430000 \\
(7)\end{array}$ & $\begin{array}{l}1.5- \\
4\end{array}$ & $\begin{array}{l}1700 \\
2000\end{array}$ \\
\hline $\begin{array}{l}\text { Mine brook } \\
\text { water }\end{array}$ & $\mu g \mathrm{~L}^{-1}$ & 260 & 14 & 51650 & 184 & 12 & 495 & 37000 & $\begin{array}{l}404000 \\
\text { (7) }\end{array}$ & 7.3 & 1930 \\
\hline $\begin{array}{l}\text { Brook } \\
\text { sediment (1) }\end{array}$ & $\mathrm{mg} \mathrm{kg}{ }^{1}$ & 300 & 2200 & 18000 & (3) & 100 & & 29000 & $\begin{array}{l}250000 \\
\text { (7) }\end{array}$ & & \\
\hline $\begin{array}{l}\text { Brook } \\
\text { sediment }\end{array}$ & $\mathrm{mg} \mathrm{kg}^{-1}$ & 200 & 5000 & 11000 & 175 & 140 & 50 & 1200 & $\begin{array}{l}170000 \\
(7)\end{array}$ & & \\
\hline \multicolumn{12}{|c|}{ Plant area and downstream } \\
\hline $\begin{array}{l}\text { Concentrate } \\
\text { (8) }\end{array}$ & wt $\%$ & 1.0 & 15.5 & 33.5 & (4) & (5) & & & 26.1 & & \\
\hline Tailings (1) & $\mathrm{mg} \mathrm{kg}{ }^{-1}$ & 257 & 6920 & 11600 & & 135 & & 5160 & & & \\
\hline Tailings & $\mathrm{mg} \mathrm{kg}^{-1}$ & 295 & 6820 & 11600 & 157 & 138 & 70 & 2800 & $\begin{array}{c}15000- \\
20000 \\
(11)\end{array}$ & & \\
\hline $\begin{array}{l}\text { Groundwater } \\
\text { near plant }\end{array}$ & $\mu g \mathrm{~L}^{-1}$ & $6-20$ & (9) & $\begin{array}{c}9000 \\
200000\end{array}$ & $\begin{array}{l}100 \\
2700\end{array}$ & $<20$ & $\begin{array}{l}50- \\
400\end{array}$ & $\begin{array}{c}700 \\
10000\end{array}$ & $\begin{array}{c}530000 \\
(7)\end{array}$ & $\begin{array}{c}5.3- \\
6.9\end{array}$ & $\begin{array}{l}1300 \\
2380\end{array}$ \\
\hline $\begin{array}{l}\text { River water } \\
\text { near plant }\end{array}$ & $\mu g \mathrm{~L}^{-1}$ & $6-10$ & $<40$ & $\begin{array}{c}2200- \\
5400\end{array}$ & $\begin{array}{l}26 \\
72\end{array}$ & (9) & $\begin{array}{l}15- \\
100\end{array}$ & $\begin{array}{l}1350- \\
4200\end{array}$ & $\begin{array}{l}55000 \\
(7)\end{array}$ & $\begin{array}{l}7.5- \\
8.3\end{array}$ & $\begin{array}{l}400 \\
1100\end{array}$ \\
\hline $\begin{array}{l}\text { River } \\
\text { sediment } \\
\text { near plant (1) }\end{array}$ & $\mathrm{mg} \mathrm{kg}{ }^{-1}$ & (9) & 95 & 157 & & 24 & & 330 & & & \\
\hline $\begin{array}{l}\text { Soil near } \\
\text { plant (1) }\end{array}$ & $\mathrm{mg} \mathrm{kg-1}$ & $\begin{array}{l}80-240 \\
\text { (1) }\end{array}$ & $\begin{array}{c}700- \\
1200(1)\end{array}$ & $\begin{array}{c}800- \\
33000(1)\end{array}$ & $\begin{array}{l}<250 \\
(1)\end{array}$ & $\begin{array}{l}<100 \\
(1)\end{array}$ & & $\begin{array}{c}900- \\
11000 \\
(1)\end{array}$ & & & \\
\hline $\begin{array}{l}\text { Groundwater } \\
\text { (irrigation) }\end{array}$ & $\mu g \mathrm{~L}^{-1}$ & 48 & $<5$ & 340 & 4 & $<5$ & 53 & 2150 & & 7.2 & 708 \\
\hline
\end{tabular}

(1) Estimated from semi-quantitative FPXRF data - (2) No data available but estimated 300 - 3000 $\mathrm{mg} \mathrm{kg}^{-1}$ from geochemical ratio - (3) No data available but estimated $100-1000 \mathrm{mg} / \mathrm{kg}$ from geochemical ratio - (4) No data available but estimated 0.1 - $1 \%$ from geochemical ratio - (5) No data available but estimated $0.25-2.5 \%$ from FPXRF measurements - (6) Estimated minimum contents from sulphide-bound metals - (7) Calculated from sulphate data - (8) Mine statistics - (9) below analytical limits - (10) Total S \% varies between 0.34 and $1.94 \%$ of which $\mathrm{SO}^{-2}$ is between 0.34 and $0.95 \%$, and the remainder (0-1.15\%) is sulphide (S) [0] - (11) Total S \% varies between 1.48 and $2.09 \%$, of which $\mathrm{SO}_{4}{ }^{2-}$ is between 0.22 and $0.24 \%$, and the remainder (1.25-1.86 \%) is sulphide (S) (CINAR \& NTUA, 2007). 


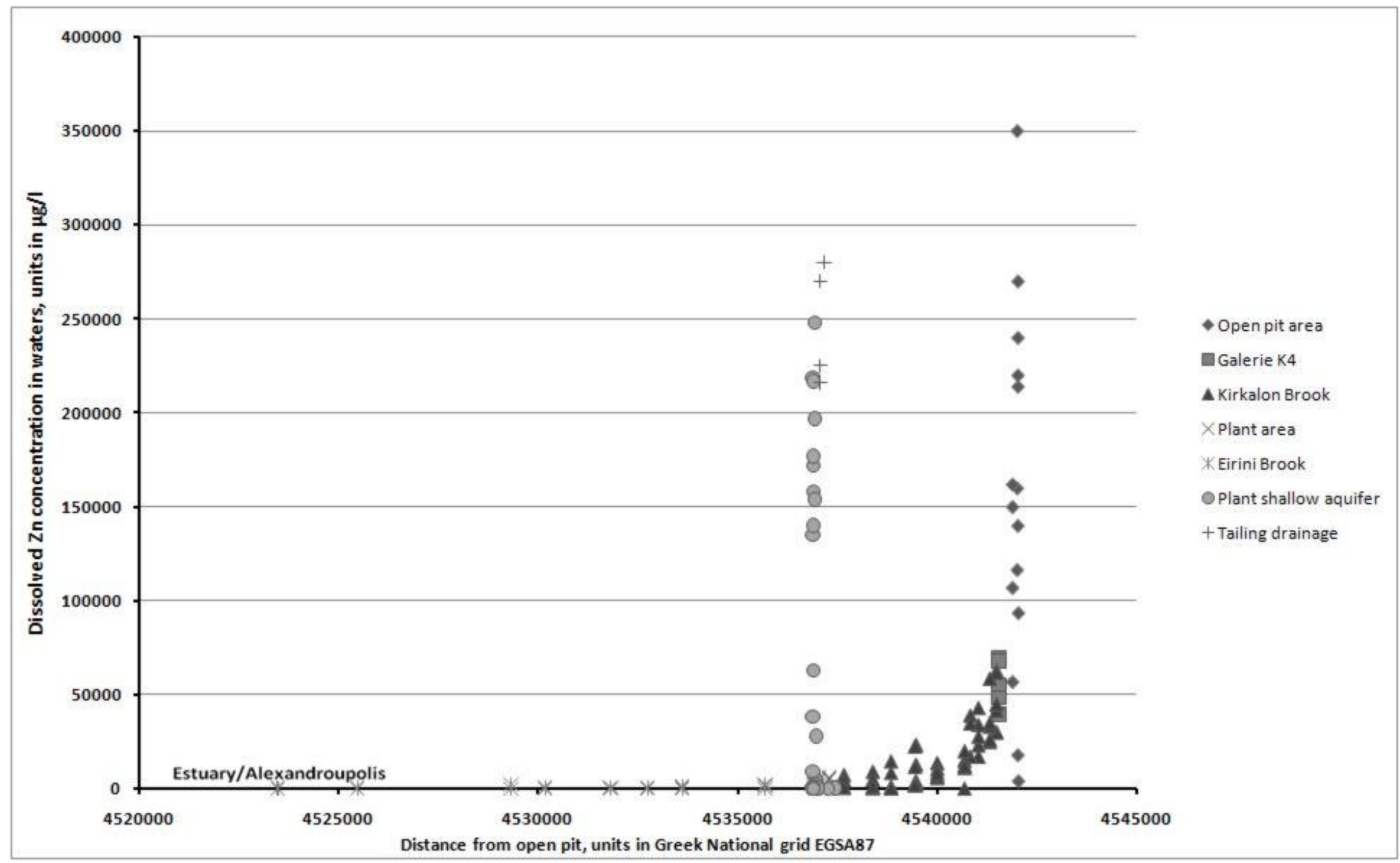

Figure 10 : Dissolved Zn concentration in waters from the Kirki mine area. 


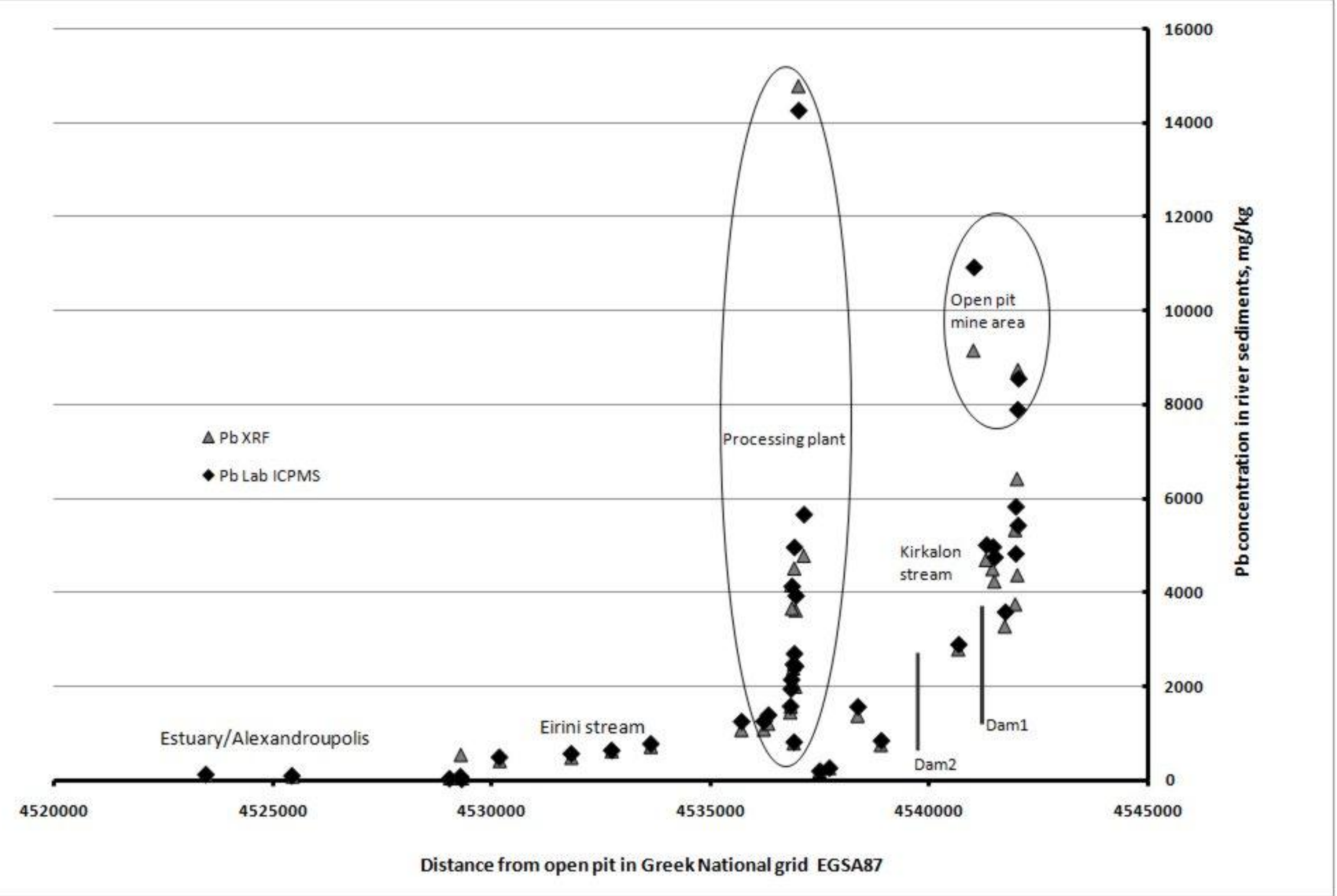

Figure $11: \mathrm{Pb}$ Concentration in Kirkalon and Eirini streams sediments. 